\title{
Development of Electronic Public Services in Agriculture
}

\author{
N.A. Safiullin ${ }^{1, *}$, Ch.M. Kurakova ${ }^{1}$, G.A. Valeeva ${ }^{1}$, I.G. Gainutdinov ${ }^{1}$ and S.S. Kudryavtseva ${ }^{2}$ \\ ${ }^{1}$ Kazan State Agrarian University, Kazan, Russia \\ ${ }^{2}$ Kazan National Research Technological University, Kazan, Russia
}

\begin{abstract}
The authors prove the relevance of the implementation of digital transformation in agricultural production and describe the main factors which constrain this process. Various approaches to the definition of the term "service" and "public service" are presented, a statistical analysis of the system for the provision of public services in electronic form is carried out and the mechanism for the implementation of public services of the Ministry of Agriculture of the Russian Federation is described. The purpose of the study is to determine the main directions of development of electronic public services in the agricultural sector based on SWOT analysis. The scientific novelty is in the proactive approach to the implementation of public services in electronic form. As a result, the authors propose to introduce the concept of super service in the process of digitalization of public services of sectoral departments, as well as other measures to improve the efficiency of electronic interaction between authorities and agricultural organizations.
\end{abstract}

\section{Introduction}

Agricultural production is characterized by a long cycle of finished products, natural risks and losses in the field of crop and livestock production, difficulties in collection and storage of agricultural products.
In 2020, the world was shocked by the coronavirus pandemic, which caused massive downtime across all the sectors of economy. However, despite the negative factors associated with the pandemic, agriculture in the Russian Federation almost did not suffer.

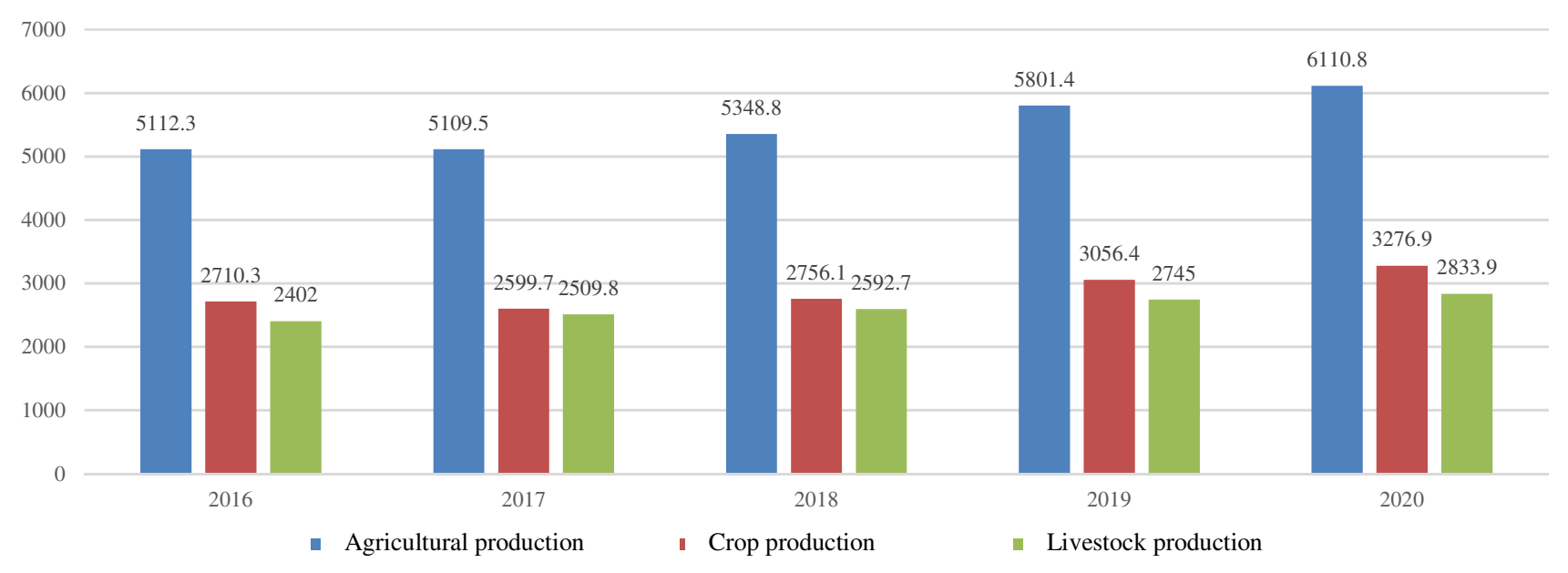

Fig. 1. Dynamics of agricultural production, in actual prices, billion rubles (preliminary data for 2020)

According to preliminary data from Russian Statistic Service, agricultural production in 2020 increased by $5.3 \%$ compared to 2019 and reached 6.1 trillion rubles in actual prices. [11] Over five years, the volume of agricultural production increased by $19.5 \%$, crop production - by $20.9 \%$, livestock - by $17.9 \%$. In comparable prices, agricultural production increased by $1.5 \%$ over the year.

The major part of agricultural production is concentrated in agricultural organizations. In 2020, they increased production by $6.3 \%$, to 3.56 trillion rubles, in comparable prices by $3.3 \%$ compared to 2019 . Almost a third of production was carried out by households. It amounted to 1.68 million rubles, in actual prices the growth was $1.1 \%$, in comparable prices there was a decrease of $3.3 \%$. Peasant (farmer) households produced products for 873.4 million rubles, while in actual prices, production increased by $10.1 \%$, in comparable terms by $3.8 \%$.

\footnotetext{
Corresponding author: nsafiullin@outlook.com
} 


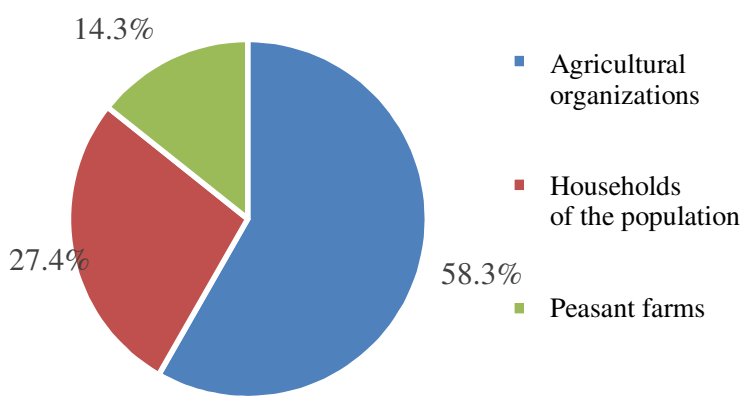

Fig. 2. Agricultural production by farm category, $\%$ (preliminary data for 2020)

Therefore, the important factor in the efficiency of agriculture is the introduction of digital technologies, including in the processes of management and interaction of an agricultural enterprise with stakeholders.

Modern mechanisms of the interaction of state bodies with agricultural organizations in the Russian Federation are determined by the quality of the provision of public services. Today, significant changes are taking place in the system of public services. According to the Decree of the President of the Russian Federation of May 7, 2012 No. 601 "On the main directions of the improvement of the public administration system" a concept for the provision of public services in electronic form is being formed. In recent years, a system of special centers, devices and virtual spaces for the provision of public services based on information and communication technologies, primarily using the Internet, has been formed in the Russian Federation.

There are various approaches to the interpretation of the concept of "service". For example, P. Kotler considers a service as an activity in which one party offers another intangible action that does not lead to its ownership. The interpretations of the concept of service in various dictionaries and regulatory legal acts are rather interesting. According to the business vocabulary of G. Bethe and B. Braindley, "a service can be perceived as an action aimed directly at a consumer; benefits provided in the form of activities; the type of goods that can be produced, transferred and consumed at the same time; changing the properties of objects without changing their belonging to a person, carried out by a supplier to a consumer".

Russian researchers A. Nozdracheva and L. Tereshchenko note that public services are "... voluntary or legally binding interaction of a client (an individual or legal entity) with an agent (an executive authority or an official), as a result of which there is a change in rights, resources and powers of clients" [9].

A public service in electronic form is the activity of executive authorities and organizations that use information, communication and digital technologies in order to provide high quality to citizens and organizations, as well as increase the efficiency of public administration.
The main normative legal act regulating the field of electronic public services is Federal Law No. 210-FL "On the organization of the provision of state and municipal services". [12] In the latest amendments to this law, new principles for the provision of services are proposed:

1. Proactive mode of service provision;

2. Registry model for fixing the result of the provision of services;

3. The principle of seamlessness in the provision of public services in non-governmental organizations

4. Electronic type of documents of personal storage

5. Digital administrative regulations and new requirements for placement in Federal Register of State Services

The decree of the President of the Russian Federation of 07.05.2012 No. 601 "On the main directions of the improvement of the system of public administration" has had a significant impact on the development of the system for the provision of public services in electronic form. By 2018, the share of citizens who use the mechanism of public services should have been at least $70 \%$. [10]

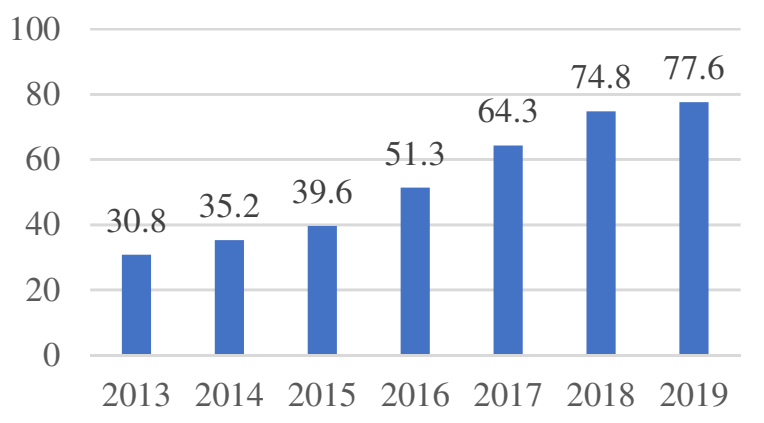

Fig. 3. Dynamics of the share of users of electronic government services in the Russian Federation, \%

State services in electronic form are provided through federal and regional portals of state and municipal services. All the data submitted in electronic form is addressed to the employees of the relevant departments for subsequent work. [6]

Today, the provision of state services in electronic form is carried out by the Service Portal of the Ministry of Agriculture of Russia. Login to the Service Portal is carried out using the account of Unified identification and authentication system.

The number of government services converted to electronic form is insufficient. It is necessary to further develop the digitalization of public services in the agricultural sector, but this is happening at a slow pace.

\section{Materials and methods}

The authors carried out a SWOT analysis and determined the strengths and weaknesses of the system for the provision of electronic public services in the field of agriculture and also identified the opportunities and threats for its development. 
Table 1. SWOT-analysis of digitalization of public services in agriculture

\begin{tabular}{|c|c|}
\hline Strengths & Weaknesses \\
\hline $\begin{array}{l}\text { 1. Readiness of the } \\
\text { infrastructure of the } \\
\text { electronic public services } \\
\text { system for the placement of } \\
\text { services in the field of } \\
\text { agriculture } \\
\text { 2. Availability of a service } \\
\text { site of the Ministry of } \\
\text { Agriculture of the Russian } \\
\text { Federation } \\
\text { 3. Willingness of civil } \\
\text { servants to refocus on the } \\
\text { provision of services in } \\
\text { electronic form } \\
4 . \text { A variety of mechanisms } \\
\text { for the provision of } \\
\text { electronic government } \\
\text { services } \\
5 \text {. Ease of mastering the } \\
\text { principles of electronic } \\
\text { government services } \\
6 \text {. Implementation of super } \\
\text { services for the proactive } \\
\text { provision of public services }\end{array}$ & $\begin{array}{l}\text { 1. Low level of interest of } \\
\text { authorities and departments in } \\
\text { the digitalization of public } \\
\text { services } \\
\text { 2. Lack of necessary } \\
\text { competencies among civil } \\
\text { servants in the field of } \\
\text { digitalization of business } \\
\text { processes } \\
\text { 3. A large number of public } \\
\text { services with a complex } \\
\text { mechanism to obtain them } \\
\text { 4. Weak system of } \\
\text { interdepartmental electronic } \\
\text { interaction of authorities } \\
\text { 5. High costs of converting } \\
\text { public services into electronic } \\
\text { form } \\
6 \text {. Lack of a clear regulatory } \\
\text { framework for digitalization } \\
\text { of public services in the field } \\
\text { of agriculture }\end{array}$ \\
\hline Opportunities & Threats \\
\hline $\begin{array}{l}\text { 1. Reduction of time spent by } \\
\text { rural producers to receive } \\
\text { services } \\
\text { 2. Expansion of the range of } \\
\text { public services based on their } \\
\text { placement on the portal } \\
\text { 3. Feedback from agricultural } \\
\text { organizations and assessment } \\
\text { of the quality of the } \\
\text { provision of public services } \\
\text { 4. Enhancement of the image } \\
\text { of state authorities among the } \\
\text { rural population } \\
\text { 5. Limitation of corruption- } \\
\text { generating factors when } \\
\text { interacting with authorities } \\
\text { 6. Rural population prefers to } \\
\text { receive government services } \\
\text { remotely }\end{array}$ & $\begin{array}{l}\text { 1. Poor cell communication in } \\
\text { remote agricultural areas } \\
\text { 2. Digital gap between rural } \\
\text { and urban populations } \\
\text { 3. Leakage risk of personal } \\
\text { data and data of } \\
\text { individuals and legal entities } \\
\text { 4. Changes in state policy in } \\
\text { the field of agriculture } \\
\text { 5. Low level of computer } \\
\text { support for agricultural } \\
\text { organizations } \\
6 \text {. Mistrust of individuals and } \\
\text { legal entities in the field of } \\
\text { agriculture to the system of } \\
\text { electronic government } \\
\text { services }\end{array}$ \\
\hline
\end{tabular}

\section{Results}

According to the results of the SWOT analysis, the authors propose the following lines of proposals, which would lead to the increase in the efficiency of the processes of the digitalization of electronic public services in the field of agriculture:

1. The power line that uses strengths and opportunities (SO). According to the national program "Digital Economy of the Russian Federation", public authorities should reorient their employees to use digital tools in their activities. This requires civil servants to have digital competencies and digital literacy skills. The Chief Digital Transformation Officer (CDTO) should be in charge of digital transformation in public authorities in the field of agriculture. In the aspect of the system of electronic public services in the field of agriculture,
CDTO is the director of their development, which is focused on the improvement of the quality of service delivery through the introduction of innovative approaches and products.

2. The improvement line uses the opportunities for leveling the weaknesses of digitalization of electronic public services in the field of agriculture (WO). The most significant activities in this line are the organization of an effective system of interdepartmental electronic interaction between various government authorities responsible for the implementation of agricultural policy, which will expand the number of provided electronic government services. The authors propose to use interactive query applications, which would be provided by the Ministry of Agriculture of the Russian Federation, as a user of electronic service through departmental information portals and regional line ministries. The next important task of this line is to form a legal framework in the field of digitalization of public services. It is necessary to develop sectoral strategies for the development of informatization of agricultural sector, as well as the concept of a mechanism for the provision of public services in the field of agriculture. The next stage in the development of the legal framework is the change in regulatory legal acts at the level of departments and regional ministries of agriculture in the aspect of the development of electronic public services. For example, the development and implementation of updated administrative regulations for the provision of services to agricultural organizations.

3. The defense line uses the strengths to reduce negative environmental factors and threats (ST). Today the further development of the concepts of e-government and service state involves the introduction of the principles of proactive provision of e-government services to individuals and legal entities. Super services as a product of this development offers a set of electronic government services depending on the life situation of a citizen. The authors propose to develop a superservice for agricultural organizations that would take into account the specifics of agriculture and offer specific state services in a specific cycle of agricultural production. For example, in the field of animal husbandry, it is proposed to introduce a super service "Animal husbandry. Online".

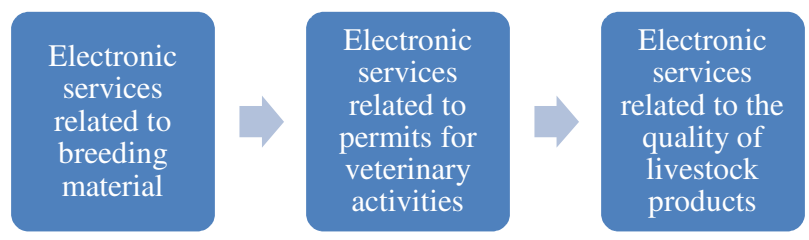

Fig. 4. Super service concept "Livestock. Online"

The introduction of such super services will reduce the digital gap between industrial and agricultural organizations, as well as increase the confidence of legal entities in the system of electronic public services in the field of agriculture.

4. The prevention line suggests the measures to prevent future risks and threats (WT). In order to reduce 
the risks associated with the security of personal data of individuals and legal entities in the provision of electronic public services in the field of agriculture, public authorities should take measures in order to improve digital literacy among civil servants. There are a large number of different advanced training courses related to the development of competencies in the field of information security. In addition, it is necessary to develop departmental regulations that describe various information security protocols. The improvement of the quality of the provision of public services in electronic form invariably leads to the increase in user confidence in the system of their provision.

\section{Conclusion}

The digitalization of public services in the agricultural sector should become a part of a more comprehensive program for the digital transformation of the industry, which will allow future reformatting of traditional agricultural organizations into digital farms that will operate on the basis of information and communication technologies.

The task of the Ministry of Agriculture of the Russian Federation should be to automate state services in the field of veterinary and phytosanitary safety, registration of fixed and circulating assets of agricultural organizations, livestock and land resources. The Department of Digital Development and Management of State Information Resources of the Agro-Industrial Complex of the Ministry of Agriculture of the Russian Federation is actively working in this direction, gradually introducing digital tools for state regulation of the agro-industrial complex.

The digital transformation of the activities of agricultural producers should be performed taking into account the priorities of the national program "Digital Economy of the Russian Federation", which involves several stages of implementation:

1. At the initial stage (2019-2021), it is planned to introduce pilot methods to stimulate the introduction of digital tools by agricultural producers. As a part of these events, it is planned to collect and analyze the data of the project participants, as well as use the data in order to form a prototype of the Digital Agriculture platform

2. At the second stage (2021-2024), the gained experience is planned to be scaled up to large and medium-sized agricultural enterprises. State support will shift towards organizations that will introduce digital technologies into their activities. At this very stage the authors propose to implement the proposed measures for the digitalization of public services.

3. At the third stage (2022-2024), the end-to-end technologies for information support of agricultural production should be created. It is planned to use private digital platforms for production management, the use of the Internet of things, as well as the widespread use of proactive state services.

The digitalization of the agro-industrial complex in general and public services in particular will increase the competitiveness and quality of labor, ensure the food security of the country and attract investment in the industry.

\section{References}

1. E.F. Amirova, L.I. Petrova, E.V. Ziuzya, V.V. Sleptsov, T.I. Krishtaleva, M.V. Kuznetsova, Import substitution as an economic incentive mechanism for Russian commodity producers, Int. J. of Civil Engin. and Technol., 10(2), 926-931 (2019)

2. T. Bournaris, Evaluation of e-Government Web Portals: The Case of Agricultural e-Government Services in Greece, Agron., 10(7), 932 (2020)

3. A. Mironkina, S. Kharitonov, A. Kuchumov, A. Belokopytov, Digital technologies for efficient farming, IOP Conf. Ser. Earth and Environ. Sci., 012017 (2020)

4. N.A. Safiullin, G.R. Valieva, D.I. Faizrakhmanov, L.N. Savushkina, Ch.M. Kurakova, Quality assessment of electronic state and municipal services using the example of the ministry of agriculture of the Russian Federation, BIO Web of Conf., 17, 00143 (2020)

5. A. Stoinescu, L. Reissig, G. Mack, Does egovernment contribute to a reduction of farmers' administrative burden in Switzerland, Busin., Computer Sci., GIL Jahrestagung (2020)

6. Unified portal of state and municipal services of the Russian Federation, Retrieved from: gosuslugi.ru (date of access: 10.03.2021).

7. I.A. Korostelkina, Possibilities of SWOT analysis in the context of the application of analytical data in the process of creating the value of an innovative product, Manag. account., 8, 26-35 (2017)

8. A.M. Magomedov, Digitalization as a key factor in the development of rural areas and agriculture, Modern manag. Technol., 2, 4 (2020)

9. N.A. Safiullin, L.N. Savushkina, Digitalization of public services in the agro-industrial complex, The coll. Devel. of the agro-industr. complex and rural areas in the context of economic modernization, Mat. of the II Int. Sci. and Pract. Conf. dedicated to the memory of N.S. Katkova (Kazan, 2020), pp. $151-153$

10. On the main directions of improving the system of public administration, Decree of the President of the Russ. Fed. of 07.05.2012, no. 601, Retrieved from: http://www.pravo.gov.ru

11. Agriculture, hunting and forestry, Federal State Statistics Service, Retrieved from: https://rosstat.gov.ru/enterprise_economy (date of access: 21.01.2021).

12. On the organization of the provision of state and municipal services, Federal Law of 27.07.2010, no. 210-FL (as amended on 30.12.2020) 